\title{
AN ANALYSIS OF THE QUALITY OF THE THICK-WALLED S355J2+N STEEL JOINT WELDED BY THE MAG METHOD
}

\begin{abstract}
An analysis of the quality of the thick-walled S355J2+N steel welded joint used most frequently in the general-building, power and other contemporary steel constructions is presented in the following article. A process of examining welding technologies was made on the tick-walled butt joints of plates by using the MAG - 135 welding method. The aim of the discussed topic was to optimize the process of welding thick-walled welded joints due to their mechanical strength properties and efficiency.

Keywords: welding, properties of joints, structural steel, non-destructive testing, destructive testing, optimizing welding conditions
\end{abstract}

\section{Introduction}

A continuous economic development on the global market initiates numerous investments in the following areas: architecture, power, metallurgy, raw material or shipbuilding industries. Mentioned investments, often connected with implementing innovative technologies, require in vast extent manufacturing large size structures which use thick-walled elements. There are structural joints in above elements, they require making numerous thick-walled welded joints, which in turn require a use of adequate technologies and proper conditions of their implementation in order to obtain suitable properties.

The aim of the following article is to make the thick-walled welding technology examination of welded joints made by the $\mathrm{S} 355 \mathrm{~J} 2+\mathrm{N}$ structural type of steel intended for proper structures in different industrial sectors including architecture and power industry. Examining a welding technology in accordance with the PN-EN ISO 15614-1 standard includes a description of welding technology, an implementation of non-destructive, and destructive testing of sample welded joints. The MAG (135) method was used to make a sample thick-walled welded joint. This method is at present the most popular, i.e. arc welding with a solid wire electrode in an active gas shield. The results of welding technology examination should provide a range of valuable information necessary to make decisions on the selection and implementation details of the correct welding technology.

\section{Characteristics of the MAG method of welding}

The MAG welding method (135) (Metal Active Gas) involves melting an edge of joined materials and a material of a consumable electrode by the heat of an electric arc in the shielding gases or gas mixtures [1]. The heat source in the MAG welding method is a welding arc glowing in the gas atmosphere between a consumable electrode and the weld material $[2,3]$. This method fully meets the requirements which are given to thickwalled joints both in terms of technology and efficiency [5-11]. This welding process is currently used in many varieties, and various forms of metal transfer in the arc welding $[4,12,13]$ In order to perform examinations the most popular method MAG (135) was used, i.e. using a standard arch. Above method can be used for high-quality joints in steel constructions including joining thick-walled elements $[14,15]$. This method guarantees obtaining the right joints in terms of technology and metallurgy for both carbon steel, low-alloy and high-alloyed and special steels [16-17]. Its great advantage is an ability to weld in all positions both in the manual and mechanized or automated processes including a use of robots.

\section{Materials used for testing}

Steel plates of 1.2 group according to the PN-CR ISO 15608 standard [6] type S355J2+N according to the PN-EN 10025-2 standard [7] were used as base materials in order to make sample butt joints. These materials belong to the well weldable steel, high strength, normalized to the overall purpose of an application

\footnotetext{
CZESTOCHOWA UNIVERSITY OF TECHNOLOGY, 69 J.H. DABROWSKIEGO STR.,42-201 CZASTOCHOWA, POLAND

Corresponding author: ryszardkrawczyk@spaw.pcz.pl
} 
for appropriate structures, inter alia architecture, for example bridges and cranes, as well as in the power industry, for example pipelines and tanks.

Structural steels type C-Mn (carbon-manganese) are characterised by the high mechanical properties. However, due to the higher value of the carbon equivalent (higher content of manganese and silicon) they are more prone to hardening in the HAZ than low-carbon types of steel. Therefore, they are also more susceptible to the formation of cold cracks.

Thus, when welding these types of steels, the following principles need to be observed [8]:

- $\quad$ an appropriate preparation of the edges of the material to be welded must be used (a distance on the threshold of the groove) and to maintain an appropriate welding sequence and method of laying beads,

- to limit an amount of hydrogen introduced into the weld through the use low hydrogen welding process and to preserve a purity of joined edges by removing dirt, rust and moisture from a welded area,

- to heat elements of a greater thickness to avoid a formation of brittle structures in an area of the HAZ,

- to use in the designed constructions appropriate structural solutions in order to limit the formation of an excessive stress.

The value of carbon equivalent $\mathrm{CEV}$ appointed for this type of steel recommended by the International Institute of Welding (IIW) from the following formula:

$$
C E V=C+\frac{\mathrm{Mn}}{6}+\frac{\mathrm{Cr}+\mathrm{Mo}+\mathrm{V}}{5}+\frac{\mathrm{Ni}+\mathrm{Cu}}{15}
$$

should reach its maximum value up to $0.47 \%$ for the material having a thickness in the range of 40 to $150 \mathrm{~mm}$.

Moreover, if they meet the following conditions on the carbon content and carbon equivalent, depending on the thickness of the material

$$
C \leq 0,20 \% \text { and } \mathrm{Ce} \leq 0,45 \% \text { and } g \leq 25 \mathrm{~mm}
$$

or,

$$
C \leq 0,20 \% \text { and } C e \leq 0,41 \% \text { and } 25<g \leq 37 \mathrm{~mm}
$$

then it can be assumed that any special precautions are necessary. However, recommendations of the International Institute of Welding must be met, for steels with the tensile strength $R_{m}=490-690 \mathrm{MPa}$ for the use of low-hydrogen welding process.

For thicker materials, i.e. above $40 \mathrm{~mm}$ these conditions are satisfied when the carbon equivalent reaches the value of $\mathrm{Ce} \leq 0.4 \%$.

If these conditions are not met, and there are other factors associated with a significant thickness of material, e.g. a degree of the joint restraint, there is a considerable risk of an appearance of hard structures as well as cold cracks. In order to decrease an above risk, it is necessary to prepare detailed parameters of welding connected with a reduction of a heat input, and a use of pre-heating to lower a speed of cooling the weld. It is recommended to use both techniques in order to weld thick elements. Pre-heating conditions can be determined on the basis of the graphs included in the PN-EN 1011-2 standard [5] for a given material thickness, heat input, a value of carbon equivalent and an amount of diffusible hydrogen.

General characteristics of C-Mn steel used in examinations of S355J2 + N type of steel is presented in Tables 1 and 2 .

\section{Examinations of welding technology}

To evaluate welding technology numerous tests on the sample welded joint were carried out assuming acceptance criteria contained in the standard for qualification for the preliminary welding procedure specification by testing welding technology according to the PN-EN ISO 15614-1 standard. Examinations were taken on the sample butt joint of thick plates prepared according to the preliminary welding procedure specification (pWPS) for an accepted MAG (135) method.

\section{Sample welded joint}

Sample welded joint is prepared in accordance with the requirements of the PN-EN ISO 15614-1 standard. This standard specifies the conditions for the preliminary welding procedure specification (pWPS) through examinations taken on the sample joint. Sample joint used for testing was made of sheet metal with dimensions of $300 \times 430 \mathrm{~mm}$ and $50 \mathrm{~mm}$ thick from the $\mathrm{S} 355 \mathrm{~J} 2+\mathrm{N}$ type of steel. The single butt joint used for weld-

\begin{tabular}{|c|c|c|c|c|c|c|c|c|c|c|c|c|c|c|c|}
\hline \multicolumn{2}{|c|}{ Type of steel } & \multicolumn{14}{|c|}{$\%$ mass } \\
\hline Symbol & Number & C & Si & Mn & $\mathbf{P}$ & $S$ & $\mathrm{Cr}$ & $\mathrm{Ni}$ & $\mathrm{Cu}$ & Al & Ti & Mo & $\mathbf{N b}$ & V & CEV \\
\hline $\mathrm{S} 355 \mathrm{~J} 2+\mathrm{N}$ & 1.0577 & 0,18 & 0,20 & 1,60 & 0,016 & 0,004 & 0,030 & 0,030 & 0,05 & 0,025 & 0,025 & 0,005 & 0,026 & 0,005 & 0,43 \\
\hline
\end{tabular}

TABLE 1

Chemical composition of steel S355J2 + N (ladle analysis according to manufacturer's certificate) [9]

\begin{tabular}{|c|c|c|c|c|c|c|c|}
\hline \multicolumn{2}{|c|}{ Type of steel } & \multirow{2}{*}{$\begin{array}{c}\text { Normal delivery } \\
\text { condition }\end{array}$} & \multirow{2}{*}{$\begin{array}{c}\text { Product thickness } \\
t,[\mathrm{~mm}]\end{array}$} & \multirow{2}{*}{$\begin{array}{c}\text { Yield strength } \\
R_{e H} \mathrm{~min},[\mathrm{MPa}]\end{array}$} & \multirow{2}{*}{$\begin{array}{c}\text { Tensile strength } \\
R_{m},[\mathrm{MPa}]\end{array}$} & \multirow{2}{*}{$\begin{array}{c}\text { Elongation at fracture } \\
\qquad A 5,[\%]\end{array}$} & \multirow{2}{*}{$\begin{array}{l}\text { Fracture work } \\
K V_{-20} \text { min, [J] }\end{array}$} \\
\hline Symbol & Number & & & & & & \\
\hline $\mathrm{S} 355 \mathrm{~J} 2+\mathrm{N}$ & 1.0577 & $+\mathrm{N}$ & 50 & 363 & 535 & 29 & 120 \\
\hline
\end{tabular}

TABLE 2

Mechanical properties according to the manufacturer's certificate [9] 

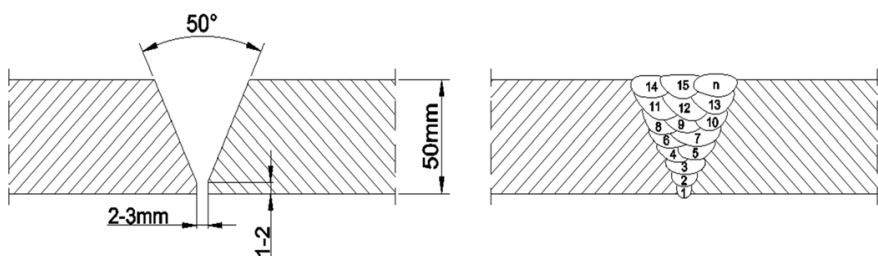

Fig. 1. A diagram of the sample joint: a) preparation for welding, b) distribution of weld beads ing by the MAG 135 method in a vertical upwards position PF was prepared by the $\mathrm{V}$ scarfing. Preliminary welding procedure specifications were prepared to make sample joints, which contain detailed conditions for welding. The most important data described in the preliminary welding procedure specification is shown in Figure 1 and in Table 3.

The welding process was performed on a welding station equipped with the welding machine with an inverter power sup-

TABLE 3

Details of the MAG method of welding in the vertical upwards position PF

\begin{tabular}{|c|c|c|c|c|c|c|c|}
\hline Bead sequence & $\begin{array}{l}\text { Welding } \\
\text { processes }\end{array}$ & $\begin{array}{c}\text { Filler metal size } \\
{[\mathrm{mm}]}\end{array}$ & $\begin{array}{c}\text { Current } \\
\text { [A] }\end{array}$ & $\begin{array}{c}\text { Voltage } \\
\text { [V] }\end{array}$ & $\begin{array}{c}\text { Travel speed } \\
\text { [cm/min] }\end{array}$ & Polarity & $\begin{array}{c}\text { Heat input } \\
{[\mathrm{KJ} / \mathrm{cm}]}\end{array}$ \\
\hline 1 & 135-D & 1,2 & $110-120$ & $17,5-18,0$ & $9,0-10,0$ & $\mathrm{DC} /+$ & $9,1-14,4$ \\
\hline 2 & 135-D & 1,2 & $130-140$ & $18,5-19,0$ & $9,0-10,0$ & $\mathrm{DC} /+$ & $10,2-14,2$ \\
\hline $3-n$ & $135-\mathrm{D}$ & 1,2 & $130-140$ & $18,5-19,0$ & $6,0-7,5$ & $\mathrm{DC} /+$ & $15,4-21,3$ \\
\hline \multicolumn{8}{|c|}{ Solid wire-classification: G3Si1 according to EN ISO 14341-A (OK Autrod 12.51) } \\
\hline \multicolumn{8}{|c|}{ Shielding gas type: CORGON 18-M21 according to PN-EN ISO 14175} \\
\hline \multicolumn{4}{|c|}{ Gas flow rate [l/min]: 14-15 } & \multicolumn{4}{|c|}{ Pre-heating temperature: $\geq 200^{\circ} \mathrm{C}$} \\
\hline \multicolumn{4}{|c|}{ Heat treatment: not applicable } & \multicolumn{4}{|c|}{ Interpass temperature: $\leq 250^{\circ} \mathrm{C}$} \\
\hline
\end{tabular}

ply cooperating with a four-roller electrode wire feeder. Welding was carried out in non-mechanized conditions involving a certified welder in this method for butt-welding metal sheets with short-circuit transfer of metal in the welding arc according to the PN-EN ISO 9606-1 standard. A copper-manganese-silicon wire electrode with a diameter of $1.2 \mathrm{~mm}$ was used to make a joint according to instructions provided in WPS. This wire is suitable for welding low-carbon and carbon-manganese types of steel in the M21 shielding gas mixture ( $82 \%$ argon, carbon dioxide, $18 \%$ ) by the MAG method. The basic data of the chemical composition of the electrode wire is shown in Table 4, and properties of the deposited metal after welding in Table 5.

A manual control of parameters was used in the process of welding, and the control of the current-voltage parameter was carried by some digital meters of the welding device. A registration of the welding time of individual weld beads was made by
TABLE 4

Chemical composition of the OK Autrod 12.51 electrode wire (according to the manufacturer's certificate) $[10]$

\begin{tabular}{|c|c|c|c|c|}
\hline \hline \multicolumn{2}{|c|}{ Type of wire } & \multicolumn{3}{|c|}{$\%$ mass } \\
\hline $\begin{array}{c}\text { Manufacturer's } \\
\text { specification }\end{array}$ & $\begin{array}{c}\text { Symbol according to the } \\
\text { EN ISO 14341-A standard }\end{array}$ & C & Si & Mn \\
\hline OK Autrod 12.51 & G 42 3 M21 G3Si1 & 0,09 & 0,90 & 1,50 \\
\hline
\end{tabular}

the hand stopwatch, and an interpass temperature control by using a thermocouple temperature meter with a point by making measurements at a distance of $50 \mathrm{~mm}$ from the weld groove in accordance with the requirements of the PN-EN ISO 13916 standard.

Actual parameters of the welding process of particular beads of a laid weld of the sample joint are shown in Table 6, while a summary of an actual heat input when welding each bead is shown in the graph (Fig. 2).

TABLE 5

Mechanical properties of the OK Autrod 12.51 electrode wire (according to the manufacturer's certificate) [10]

\begin{tabular}{|c|c|c|c|c|c|c|c|}
\hline \multicolumn{2}{|c|}{ Type of wire } & \multirow[b]{2}{*}{ Condition } & \multirow[b]{2}{*}{$\begin{array}{l}\text { Diameter } \\
d,[\mathrm{~mm}]\end{array}$} & \multirow[b]{2}{*}{$\begin{array}{c}\text { Yield strength } \\
R_{e H} \text { min, [MPa] }\end{array}$} & \multirow{2}{*}{$\begin{array}{c}\text { Tensile } \\
\text { strength } \\
\boldsymbol{R}_{m},[\mathrm{MPa}]\end{array}$} & \multirow{2}{*}{$\begin{array}{c}\text { Elongation } \\
\text { at fracture } \\
\boldsymbol{A} 5,[\%]\end{array}$} & \multirow{2}{*}{$\begin{array}{l}\text { Fracture work } \\
K V_{-20} \text { min, }[\mathrm{J}]\end{array}$} \\
\hline $\begin{array}{c}\text { Manufacturer's } \\
\text { specification }\end{array}$ & $\begin{array}{l}\text { Symbol according to the } \\
\text { EN ISO 14341-A standard }\end{array}$ & & & & & & \\
\hline OK Autrod 12.51 & G 423 M21 G3Si1 & after welding & 1,2 & 470 & 560 & 26 & 90 \\
\hline
\end{tabular}

TABLE 6

Actual parameters of the welded sample joint of the S355J2 + N type of steel

\begin{tabular}{|c|c|c|c|c|c|c|c|c|c|c|c|c|c|c|c|c|c|c|c|c|c|}
\hline \multirow{2}{*}{ Data of the process } & \multicolumn{21}{|c|}{ No of the bead } \\
\hline & 1 & 2 & 3 & 4 & 5 & 6 & 7 & 8 & 9 & 10 & 11 & 12 & 13 & 14 & 15 & 16 & 17 & 18 & 19 & 20 & 21 \\
\hline Welding time $t[\mathrm{~s}]$ & 276 & 261 & 372 & 444 & 366 & 432 & 414 & 417 & 345 & 372 & 420 & 342 & 315 & 474 & 348 & 345 & 483 & 333 & 357 & 564 & 561 \\
\hline $\begin{array}{c}\text { Welding speed } \\
v[\mathrm{~cm} / \mathrm{min}]\end{array}$ & 9,8 & 10,3 & 7,3 & 6,1 & 7,4 & 6,3 & 6,5 & 6,5 & 7,8 & 7,3 & 6,4 & 7,9 & 8,6 & 5,7 & 7,8 & 7,8 & 5,6 & 8,1 & 7,6 & 4,8 & 4,8 \\
\hline Arc power $N[\mathrm{~kW}]$ & 1,6 & & & & & & & & & & 2, & 03 & & & & & & & & & \\
\hline $\begin{array}{c}\text { Heat input welding } \\
Q[j J / \mathrm{cm}]\end{array}$ & 10,0 & 11,7 & 16,7 & 20,0 & 16,5 & 19,4 & 18,6 & 18,8 & 15,5 & 16,7 & 18,9 & 15,4 & 14,2 & 21,3 & 15,7 & 15,5 & 21,7 & 15,0 & 16,1 & 25,4 & 25,2 \\
\hline
\end{tabular}




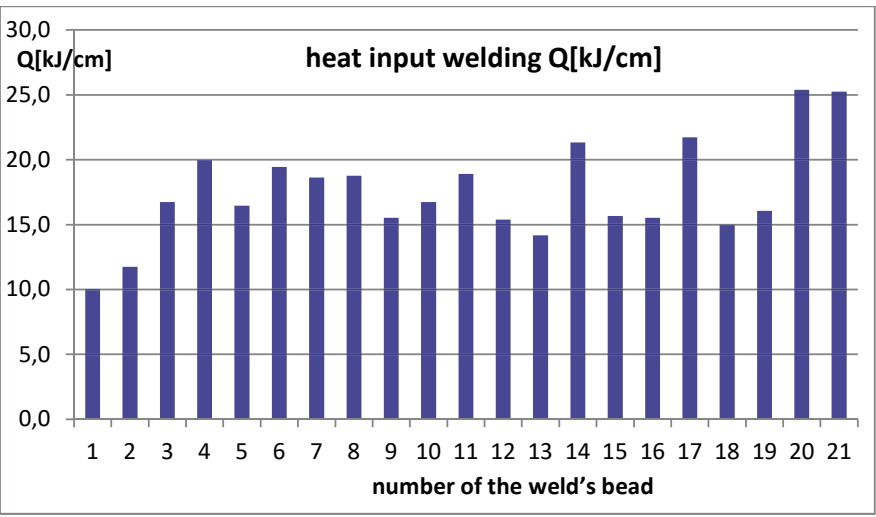

Fig.2. Actual value of heat input welding while welding individual beads

The first penetration bead and the first filling bead are made with the least heat input welding process (10 and $11.7 \mathrm{~kJ} / \mathrm{cm}$ ), which was influenced by the lower arc power and the greater speed of welding. In turn, the last two filling beads were made with the biggest heat input of the welding process (approx. $25 \mathrm{~kJ} / \mathrm{cm}$ ) resulting from the low speed of welding forced to obtain the proper filling of the weld groove. Remaining beads of the welded joint, i.e. 3 to 19 , were made by the heat input of welding process in a range from 14.2 to $21.7 \mathrm{~kJ} / \mathrm{cm}$.

Sample joint was made in a total time of 5.5 hours including a welding time and necessary breaks for cleaning welds and a control of an interpass temperature (a total time of welding all the beads was 2.5 hours).

A view from the weld's face of the sample joint made by the MAG method is shown in Figure 3.

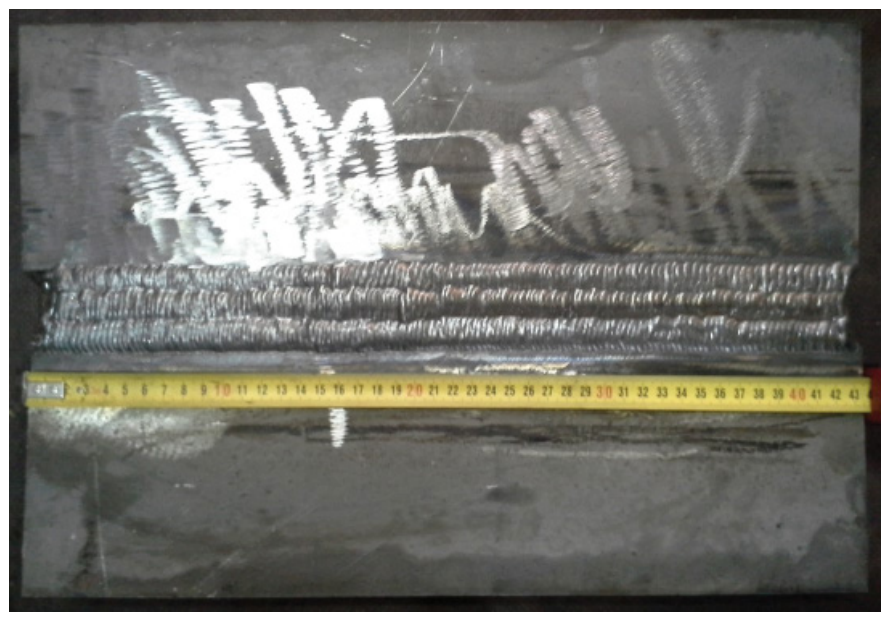

Fig. 3. A view of a sample welded joint from the weld's face

\section{Examinations of a sample welded joint}

Checking a welding technology according to the PN-EN ISO 15614-1 standard requires testing a sample joint in accordance with the requirements contained in table 6 , and relating to the examined example, i.e. a single butt joint of sheets of considerable thickness with a full penetration.
TABLE 6

A scope of inspection and examination of sample joints according to the PN-EN ISO 15614-1 standard [8]

\begin{tabular}{|c|c|c|}
\hline \hline Sample joint & Type of examination & $\begin{array}{c}\text { Scope of } \\
\text { inspection }\end{array}$ \\
\hline & Visual testing & $100 \%$ \\
A single & Radiographic or ultrasonic testing & $100 \%$ \\
butt joint & Detecting surface cracks & $100 \%$ \\
with a full & Transverse tensile test & 2 samples \\
penetration & Transverse bending test & 4 samples \\
& Impact strength test & 2 required sets \\
& Hardness test & 1 sample \\
\hline
\end{tabular}

First of all, each sample joint was subjected to non-destructive testing to the full extent, i.e. visual testing (VT), magneticpowder testing (MT), ultrasonic testing (UT) and radiographic testing (RT). An amount of research methods was increased in relation to the requirements of the PN-EN ISO 15614-1 standard by the radiographic examination. All the examinations were taken after 48 hours after the welding process. Quality level B of welded joints was accepted in accordance with the PN-EN ISO 5817 standard. Appropriate standards of examination were agreed to do non-destructive testing as well as an assessment of joints was adopted, which is presented in Table 7.

TABLE 7

Relevant standards used to do NDT

\begin{tabular}{|c|c|c|}
\hline \hline Testing method & Testing & Acceptance criteria \\
\hline Visual testing VT & PN-EN & PN-EN \\
& ISO 17637 & ISO 5817 - B \\
\hline $\begin{array}{c}\text { Magnetic-powdered } \\
\text { MT testing }\end{array}$ & $\begin{array}{c}\text { PN-EN } \\
\text { ISO 17638 }\end{array}$ & $\begin{array}{c}\text { PN-EN } \\
\text { ISO } 23278-2 x\end{array}$ \\
\hline \multirow{2}{*}{ Ultrasonic testing (UT) } & $\begin{array}{c}\text { PN-EN } \\
\text { ISO 17640 }\end{array}$ & $\begin{array}{c}\text { PN-EN } \\
\text { ISO 11666-2 }\end{array}$ \\
\hline \multirow{2}{*}{ Radiographic testing (RT) } & $\begin{array}{c}\text { PN-EN } \\
\text { ISO 17636 }\end{array}$ & $\begin{array}{c}\text { PN-EN } \\
\text { ISO 10675-1 }\end{array}$ \\
\hline
\end{tabular}

Samples for destructive testing were taken after obtaining positive results of successively done NDT on the sample joint including the tensile test, bending, impact strength, macroscopic examination and hardness distribution. Appropriate standards of examination were agreed to do non-destructive testing as well as an assessment of joints was adopted, which are presented in Table 8 .

TABLE 8

Relevant standards used to do destructive testing

\begin{tabular}{|c|c|c|}
\hline \hline Testing method & Testing & Acceptance criteria \\
\hline Tensile test & PN-EN ISO 4136 & Min $R_{m}=470 \mathrm{MPa}$ \\
\hline Bending test & PN-EN ISO 5173 & Bending angle 180 \\
\hline Impact strength test & PN-EN ISO 9016 & Min $K V_{\left(-20^{\circ} \mathrm{C}\right)}=27 \mathrm{~J}$ \\
\hline $\begin{array}{c}\text { Macroscopic } \\
\text { examination }\end{array}$ & PN-EN ISO 17639 & PN-EN ISO 5817- B \\
\hline Hardness test & PN-EN ISO 9015-1 & Max 380 (HV10) \\
\hline
\end{tabular}




\section{Results of testing sample welded joints}

Positive results of testing sample welded joint in both nondestructive and destructive testing were obtained according to an approved scope and acceptance criteria set out above. Detailed results of non-destructive testing are presented in Table 9.

TABLE 9

Results of NDT of sample welded joints

\begin{tabular}{|c|c|c|c|c|c|}
\hline \hline \multirow{2}{*}{ Type of joint } & \multicolumn{4}{|c|}{$\begin{array}{c}\text { Results of NDT } \\
\text { according to } \\
\text { acceptance criteria }\end{array}$} & \multirow{2}{*}{ Comments } \\
\cline { 2 - 5 } & VT & MT & UT & RT & \\
\hline $135 / \mathrm{S} 355 \mathrm{~J} 2+\mathrm{N}$ & $\mathrm{B}$ & $2 \mathrm{X}$ & 2 & 1 & $\begin{array}{c}\text { Lack of welding defects } \\
\text { and registered indications }\end{array}$ \\
\hline
\end{tabular}

Results of non-destructive testing confirm required acceptance criteria. There is a lack of welding defects or registered indications in VT, MT, RT and UT testing. A few small indications of a lower amplitude than the required level of registration were not assessed or included in the registration in UT on an adopted acceptance level 2 [11].

Detailed results of destructive testing are presented in the following Tables 10-13.

TABLE 10

Results of tensile and bending test of sample welded joints

\begin{tabular}{|c|c|c|c|c|c|c|}
\hline \hline \multirow{2}{*}{ Type of joint } & \multicolumn{3}{|c|}{ Results of tensile test } & \multicolumn{2}{|c|}{$\begin{array}{c}\text { Results of bending } \\
\text { test }\end{array}$} \\
\cline { 2 - 7 } & $\begin{array}{c}\boldsymbol{R}_{\boldsymbol{m}} \text { av } \\
{[\mathrm{MPa}]}\end{array}$ & Grade & Fracture & $\boldsymbol{\alpha}\left[^{\mathbf{0}}\right]$ & Grade & Cracks \\
\hline $135 / \mathrm{S} 355 \mathrm{~J} 2+\mathrm{N}$ & 537 & + & $\begin{array}{c}\text { base } \\
\text { material } / \\
\text { no defects }\end{array}$ & 180 & + & Lack \\
\hline
\end{tabular}

Both tensile and bending tests done by the 135 method in the vertical upwards position PF of a sample welded joint gave positive results. Rupture occurred in the base material in tensile tests, and there were no discontinuities on fractures. A desired angle of bending without cracking was obtained in side bending tests. Requirements for testing of welding technology were also fulfilled. Samples after testing are shown in Figure 4.

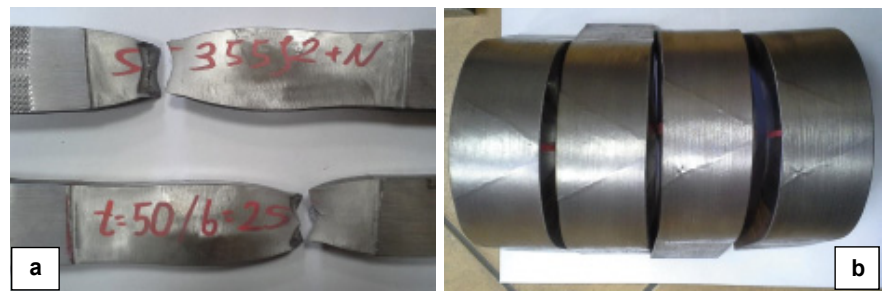

Fig. 4. A view of samples after testing: a) tensile test b) bending test (from the tensile side)

Measurements of a hardness distribution of the welded joint were made at the cross section in the two measurement lines from the face of the weld (no. I) and from root of the weld (no. II) in each of the five zones, i.e. in the weld and in the HAZ, and in the base material on each side of the weld. Hardness tests were performed in accordance with the requirements of the PN-EN ISO 9015-1 standard by the Vickers method with a load of $100 \mathrm{~N}$, i.e. HV10. Test results of the hardness distribution of the welded joint are presented in Table 11, and changes of average values in individual zones are shown in the graph illustrated in Fig. 5.

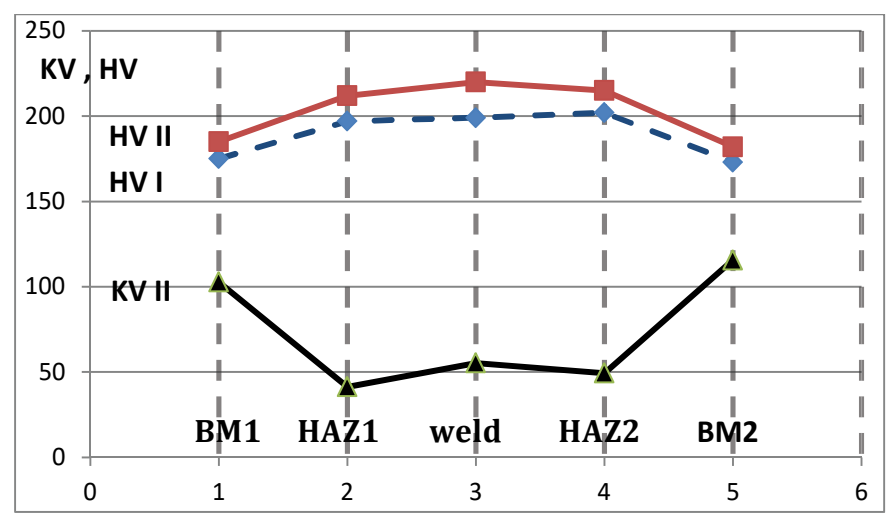

Fig. 5. Results of the distribution of average values of hardness and fracture work in various zones of the joint

The highest level of hardness was obtained in the second measurement line from the root of the weld in the material of the weld of the first penetration bead, and slightly lower levels in both heat-affected zones. Base material was characterized by the lowest hardness. In all examined areas a level of hardness

TABLE 11

Results of hardness test of sample welded joints

\begin{tabular}{|c|c|c|c|c|c|c|c|c|c|}
\hline \multirow{2}{*}{ Lo } & \multirow{2}{*}{$\begin{array}{c}\text { Determination } \\
\text { of the sample }\end{array}$} & \multirow{2}{*}{$\begin{array}{c}\text { No. of a } \\
\text { measurement }\end{array}$} & \multicolumn{5}{|c|}{ Results } & \multirow{2}{*}{ Grade } & \multirow{2}{*}{ Comments } \\
\hline & & & Base material 1 & HAZ1 & Weld & HAZ2 & Base material 2 & & \\
\hline \multirow{8}{*}{1} & \multirow{8}{*}{$135 / \mathrm{S} 355 \mathrm{~J} 2+\mathrm{N}$} & \multirow{3}{*}{ I } & 180 & 187 & 206 & 201 & 170 & + & - \\
\hline & & & 171 & 188 & 199 & 206 & 172 & + & \\
\hline & & & 174 & 216 & 193 & 199 & 177 & + & \\
\hline & & I average & 175 & 197 & 199 & 202 & 173 & + & \\
\hline & & \multirow{3}{*}{ II } & 182 & 193 & 224 & 209 & 184 & + & \\
\hline & & & 183 & 235 & 213 & 220 & 180 & + & \\
\hline & & & 189 & 207 & 224 & 216 & 181 & + & \\
\hline & & II average & 185 & 212 & 220 & 215 & 182 & + & \\
\hline
\end{tabular}


confirmed good plastic properties of the joint, and thus correct parameters and a proper implementation of welding technology.

The impact test was done in accordance with the requirements of the standard Charpy V test at $\left(-20^{\circ} \mathrm{C}\right)$. Samples were taken from the lower joint area of all the zones, i.e. weld, HAZ1 and 2 , and materials of joined sheets. Test results are provided in Table 12.

Higher value of fracture work was achieved in the area of the weld of the welded joint, and slightly lower in the heat affected zone. The requirements for impact tests of an examined welding technology of thick-walled welded joints have been met.
The results of hardness distribution and fracture work in specific zones of the welded joint is illustrated in the diagram (Fig. 5).

Macroscopic examination was carried out on a cross-sectional sample taken from an initial section of the sample joint. The test result is shown in Table 13.

The result of the macroscopic examination showed a proper structure of a thick-walled joint. There are no welding defects in the examined section. The thick-welded joint meets the quality level B according to the PN-EN ISO 5817 standard.

TABLE 12

Results of impact test of sample welded joints - fracture work $\mathrm{KV}\left(-20^{\circ} \mathrm{C}\right)$

\begin{tabular}{|c|c|c|c|c|c|c|c|c|}
\hline \multirow{2}{*}{ Type of joint } & \multirow{2}{*}{$\begin{array}{l}\text { Area of an } \\
\text { examination }\end{array}$} & \multicolumn{5}{|c|}{ Results of $K V_{(-20)}[\mathrm{J}]$ tests } & \multirow{2}{*}{ Grade } & \multirow{2}{*}{ Comments } \\
\hline & & BM 1 & HAZ1 & WELD & HAZ2 & BM 2 & & \\
\hline \multirow{4}{*}{$135 / \mathrm{S} 355 \mathrm{~J} 2+\mathrm{N}$} & \multirow{3}{*}{ II } & 111 & 42 & 48 & 48 & 122 & + & - \\
\hline & & 103 & 35 & 56 & 46 & 117 & + & - \\
\hline & & 94 & 47 & 62 & 54 & 108 & + & - \\
\hline & average & 102,7 & 41,3 & 55,3 & 49,3 & 115,7 & + & - \\
\hline
\end{tabular}

TABLE 13

A result of the macroscopic examination of the sample welded joint

\begin{tabular}{|c|l|}
\hline \hline A view of the cross-section of the joint & \multicolumn{1}{|c|}{ Description } \\
\hline | & $\begin{array}{l}\text { The butt joint of plates made properly as the single 21-bead. } \\
\text { A face of the weld is flat, even with a smooth transition from } \\
\text { the weld to the surface of sheet which makes the butt joint. } \\
\text { A width of the HAZ in the range up to } 2 \text { mm. There is a lack } \\
\text { of internal welding defects. There is a visible dark line of } \\
\text { a different structure in the middle zone of the base material } \\
\text { on the left side of the weld. A view of a real macroscopic } \\
\text { cross-section is shown in the picture on the left. }\end{array}$ \\
Zoom $\times 1$ Nital etched & \\
\hline
\end{tabular}

\section{Summary}

It can be assumed on the base of taken examinations that developed conditions of the MAG method of welding and their implementation for the thick-walled butt joint of carbon-manganese steel type S355J2 + N ensure that joints will be properly made. It is confirmed both by the results of non-destructive testing as well as the results of destructive tests.

An obtained joint showed good plastic properties confirmed in studies of both bending, hardness distribution as well as impact strength. Mentioned joint also proved a proper mechanical strength. A properly conducted process with appropriate parameters and appropriate supervision allowed to avoid the risks associated with the tendency of the steel to form hard structures, especially in the heat affected zone of thick-walled joints. Such increased risk occurred in an initial phase of the welding joint during making the first beads, where the higher hardness and lower fracture work were obtained in both the HAZ and the weld material. It was directly linked to the processing conditions, i.e. a need to use low parameters in the welding process, a relatively low temperature of welded materials (although pre-heating was used), and a relatively intensive heat dissipation to materials due to be joined. Slight variations obtained in an assessment of the joint's property in the particular zones of the joint result from a variability of conditions occurring in the non-mechanized welding process and should not affect a safe operation of the structural facility. In addition to the good properties of the joint, a high welding efficiency for thick-walled joints was also obtained, which is extremely important. Implemented process is also adequate for welding constructions of complex shapes (often difficult to access), which requires the use of different welding positions. 


\section{REFERENCES}

[1] PN-EN ISO 4063:2011; Spawanie i procesy pokrewne-Nazwy i numery procesów.

[2] Praca zbiorowa; Poradnik inżyniera-Spawalnictwo tom II, WNT, Warszawa (2005).

[3] B. Pierożek, J. Lassociński, Spawanie łukowe stali w osłonach gazowych. WNT Warszawa (1987).

[4] R. Krawczyk, Zakresy parametrów spawania w zależności od przenoszenia metalu w huku spawalniczym. Biuletyn Instytutu Spawalnictwa 4, 57-63 (2014).

[5] PN-EN 1011-2:2008; Spawanie-Wytyczne dotyczące spawania metali-Część 2: Spawanie łukowe stali ferrytycznych.

[6] PN-EN 10025-2:2008; Wyroby walcowane na gorąco ze stali konstrukcyjnych-Część 2: Warunki techniczne dostawy stali konstrukcyjnych niestopowych.

[7] J. Brózda, Stale konstrukcyjne i ich spawalność, Instytut Spawalnictwa, Gliwice (2009).

[8] PN-EN ISO 15614-1:2008; Specyfikacja i kwalifikowanie technologii spawania metali-Badanie technologii spawania-Część 1: Spawanie łukowe i gazowe stali oraz spawanie łukowe niklu i stopów niklu.

[9] Świadectwo odbioru wytwórcy 3,1; blacha t30 S355J2+N-firmy METINVEST.

[10] Atest wytwórcy materiałów spawalniczych, drut elektrodowy OK Autrod 12.51-firmy ESAB.
[11] R. Kaczmarek, R. Krawczyk, Projektowanie i wytwarzanie konstrukcji spawanych w aspekcie możliwości przeprowadzania badań ultradźwiękowych wykonywanych złączy, Przegląd Spawalnictwa 86, 7, 22-29 (2014).

[12] J. Deputat, Badania ultradźwiękowe Podstawy. Instytut Metalurgii Żelaza im. Stanisława Staszica, Gliwice, (1979).

[13] PN-EN 10228-3:2000 Badania nieniszczące odkuwek stalowych Badanie ultradźwiękowe odkuwek ze stali ferrytycznych i martenzytycznych.

[14] R. Kaczmarek, Analiza dokładności wyznaczenia położenia nieciagłości punktowych w badaniach ultradźwiękowych z wykorzystaniem głowic podwójnych, Przegląd Spawalnictwa 10, 5-7 (2015).

[15] T. Węgrzyn, J. Piwnik, B. Łazarz, W. Tarasiuk, Mechanical properties of shaft surfacing with micro-jet cooling, MECHANIKA 21, 5, 419-423 (2015).

[16] R. Burdzik, T. Weggrzyn, Ł. Konieczny, A. Lisiecki, Research on influence of fatigue metal damage of the inner race of bearing on vibration in different frequencies, Archives of Metallurgy and Materials 59, 4, 1275-1281 (2014).

[17] G. Golanski, A. Zielinski, J. Słania, et al. Mechanical properties of VM1 2 steel after $30000 \mathrm{hrs}$ of ageing at 600 degrees c temperature, Archives of Metallurgy And Materials 59, 4, 1351-1354 (2014).

[18] T. Węgrzyn, J. Piwnik, D. Hadryś, Acicular ferrite in micro welding technologies, Archives of Metallurgy and Materials 59, 2, (2014). 